\title{
What trees taught me about Covid-19: on relational accounting and other magic
}

\begin{abstract}
On trees
"Do you think trees grow slower this year or is it us who take the time to see them grow?", my friend asked. "Probably, both," I answered. After eight weeks of confinement, I started wondering whether trees had actually decided not to bloom as per their usual. "I mean, there is no reason for them to be looking forward to the summer. I would probably hibernate a little longer too." I continued. My friend acquiesced, "Speed is the problem. We go too fast in this world, always doing something, running. Why? We need to slow down."

I have been observing trees for several years now. When I left Paris five years ago to live in the Forest City, a small college town in the middle of the Great Lakes, most of my friends believed that I was becoming foolish, going through a sort of countryside parental crisis. That was not completely wrong. I could not stand the concrete anymore: Canada and its wilderness looked appealing. Yet, I admit it, I was terrified too. How the snobbish Parisian I was could survive in the boonies? In the middle of the Covid-19 crisis, my big city friends, as I called them, were now envying my situation, "You are so lucky to have this house, this yard, and this forest nearby." I concurred, the forest was reassuring. Among the trees, it seemed that the world was actually not collapsing, just going a bit slower than usual.

Amidst this global pandemic, going into the woods had become my new routine. As I was observing the world in lock down, witnessing the trees grow felt like a little victory -a reempowerment of myself, an act of independence and a French rebellion against this whole universe that was taking away all my agency and power. Every evening, by the river, I could become this strong human being in charge of her life again, this superwoman knowing exactly what to do and this individual successfully making sense of the nonsense. As the sun was going down, listening to the frogs and spotting the bats, I was waiting for the little inspiring particles that trees were supposed to send me. My Indigenous friends and the talks on TEDx were clear: Trees would show me the way - I just needed to listen to them.

After weeks of daily walks, touching dozens of barks and hours observing the river, I had to come to the harsh but true conclusion that the trees were not ready to speak to me. If anything, I felt that the forest was extremely slow to blossom and that the floor was really muddy and wet. I was cold, and this little game that trees were playing with me started to be unnerving. My research productivity was close to null, I came to hate zoom, the social distancing patterns drawn on the supermarket's floor depressed me and the online school program of Grade 3 and SK I had to supervise everyday drove me nuts. I wondered why I had
\end{abstract}

The author wants to thank all the Indigenous leaders who have opened their hearts and their souls and shared with the authors their knowledge and love of Gaia and her spirits. This essay is a humble homage to their courage, faith and humanity and hopefully a little stone on the path towards truth and reconciliation [6]. The author also wants to thank Editor Steve Evans and the editorial team of the Accounting, Auditing and Accountability Journal (AAAJ) who created the space for alternative forms of expression and knowledge in their journal. Without the support of existing academic institutions, decolonization will unfortunately remain unachievable. This article received the Best Paper Award in the category "Covid-19," XX USP International Conference in Accounting.

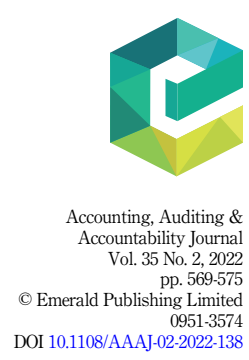


AAAJ

35,2

570

to pretend that each math exercise was as exciting as a birthday party, that we would all grew together from this experience and that the economy could transition towards green growth if we really wanted it. While the reality was that the world was falling apart, the trees refused to tell me their secrets, and my potential contribution as an accounting academic to the recovery was, to say the least, unclear.

I did not understand the trees. And I was puzzled. There were already a few years since I started learning about the spirits of the forest, thanks to the Indigenous conservationists I was working with. Yet when I needed trees' guidance the most, I could not feel anything. I was like a cool vegan trying to reconnect with my soul by flying across the ocean to a meditating one-week luxury camp serving soups and smoothies. The forest was reenergizing, pleasant to walk by, sometimes liberating but was not teaching me anything I could not read on Facebook. I was clearly missing something.

\section{On naming}

I decided to sit down and think about what I had learnt since I arrived. I remembered a discussion with an Indigenous leader two years before: "You have to name the plants for them to exist." Fair enough, I thought: I would learn their names then. As flowers and birds began to timidly appear behind the leaves, I photographed them. Each evening was dedicated to give a name to the species I encountered during the day and learn about their habitats and lives. I read about their scientific names, their needs for water and sun, their life expectancy but also their secrets, meanings and roles according to the First Nations communities living in the region. Deer became spirit animals teaching me about resilience and unconditional love, beavers: symbolic incarnation of the fur trade and the associated conquest of the West and dandelions: potential salad substitutes in a messed-up supply chain of fresh food.

A Saturday, an exciting piece broke the news: I was almost sure that I saw five huge black redhorse fishes in the river, a threatened species. I was truly excited, almost as much as when I heard the word deconfinement for the first time. As I was about to compulsively share the news with all my family and friends on WhatsApp, I suddenly realized that if I did that, I would appear completely crazy to all my relatives stuck in their flats in Paris, London or Manila. As much as I wanted to share my discoveries with the entire world, I did not know how to explicate that deer did teach me about acceptance and trees about life, without sounding like a new age one under influence. The forest was teaching me something I did not know how to explain.

I used to be puzzled: I was from then on inspired. I was starting not only to understand but truly feel in my entire body what the Indigenous teachers had told me over the years: The stones were actually my ancestors. The trees I was seeing and touching were the great granddaughters of trees that were there hundreds of years ago. A network of roots underneath was linking all those living and dormant species, nurturing the soil for all the plants that were slowly growing, providing seeds for all the birds that were migrating over and offering me a place where I could hide and breathe. There was a web of connections that had maintained life for 10,000 years, and I was part of it. I was there, at this very moment, celebrating life while mourning the deaths of hundreds of thousands of people over the world because a beaver, whose great great grandson I was watching, attracted some settlers hundreds of years ago, and a pangolin far away decided that I could not socialize with other human beings anymore. The trees eventually spoke to me: I indeed just needed to listen to them.

"You have to name things for them to exist." I recalled. I had to name the connections to the trees, the animals, the dead and those to be born I experienced in this tiny forest, somewhere lost on the planet during a plague of an unusual magnitude. "It is like relational 
accounting." I explained to my friend, as we walked by the river. "Relational accounting, not like an empty useless theoretical concept that exists only in our papers. I mean true relational accounting, an accounting of our relationships to each other, to the ecosystems to which we belong, to the generations that came before us, to those will come after us, to the magic that surrounds us. This Covid-19 crisis is both bigger and smaller than us. This is what accounting should be about - rendering our relationships visible, naming them, feeling them, connecting each other, humans and non-humans, celebrating life, mourning the dead, like we do it, now, in this forest. This transactional, incentive-based view of accounting is non-sense." My friend smiled, "You are right. This beaver is definitely a cool one. It deserves to be talked about."

\section{On relational accounting and other magic}

Before the lock down, relational accounting was a nice theoretical concept that I cognitively cuddled, but that I never really felt. While economics portrays human beings as rational Homo economicus willing to maximize their own benefits, relational sociology places social relationships at the center of economic action (Wherry, 2016). Human beings engage with each other in a way that maintains the social structures in place, even if protecting the collective comes at their individual costs. If anything, the confinement put in place during the pandemic was a collective reminder of this social life. There is indeed nothing in our accounts that does not carry a vision and an embodiment of our relationships: We are our accounting fabric.

As a qualitative accounting scholar, I was fully aware of the social construction of our accounting systems and of their performative effects before Covid-19 erupted. Yet I had to slow down, to observe, days after days, weeks after weeks, the same river, the same trees and the same nests, to start seeing what they had to teach me. I had to take the time to listen and feel, to sit down without waiting for anything, to connect to my fellow human beings trapped in the same dramatic state and to eventually find what I was looking for: the secrets of the trees. I am sure many people had a similar experience, wherever they were during the confinement: observing the birds from a balcony, feeling the sun through the window, touching the grass in the park and wondering how a little virus appearing on a wildlife market somewhere on the globe could impact the entire planet.

What did nature(s) tell us during this time of crisis that we could not hear before? As I was reflecting on what happened, an Indian healer to whom I sent my essay commented: "Trees blossom when they are ready. It is like this virus, it is alive and therefore has a spirit. It is just like any other living thing." While I was reading those words, the difference between the sociological account of relational accounting and the one I experienced amidst the trees struck me. Our relations with each other are much broader than the human ties that surface in our daily lives. They include the people who were here before us, those who are with us today and those who will be there after us, but also the viruses, the flowers, the trees and the animals. Beavers and pangolins have played in my life a role as important as human beings I deemed essential to my intellectual journey. They taught me things that no reading or writing has ever shown me. They made me understand that everything that had, has or will have a life - a spirit - and has some connections with us, in a way or another.

When the world stopped in March 2020 and human beings had nothing to do but listening, they started hearing again what trees had to tell them. They built a relational account with others, humans and nonhumans that appealed to their experience of the spiritual - i.e. life - in its different forms rather than through the outcomes of their transactions with those very beings. For some weeks, the sacred in our relationships did 
AAAJ

35,2

reappear. The lure of our collective end made our sentiments and feelings bloom again. We had to abandon our plans, our certainties, our rationale to embrace the unknown, the present and the divine. We got to worry, to cry, to hope, to miss, to care and to love, all again.

As I was erring in my thoughts, The Logical Song performed by Supertramp in 1979 started playing in my ears. While I was listening to it, I could not but notice the sadness of the lyrics and their echoes with the situation of today.

When I was young, it seemed that life was so wonderfulA miracle, oh it was beautiful, magical And all the birds in the trees, well they'd be singing so happily Oh joyfully, playfully watching me

But then they send me away to teach me how to be sensible

Logical, oh responsible, practical

And they showed me a world where I could be so dependable

Oh clinical, oh intellectual, cynical

The song portrays magic and nature as belonging to a childhood that humans were forced to abandon. The modern world decided that rationality and calculation were the signs of adulthood, transforming capitalism into a white man, lonely and suffering. Meanwhile, Aboriginal communities all over the planet struggled and died to protect an enchanted web of connections that was living underneath our feet. Through their melody and prose, musicians are here to remember this magical world we attempted to destroy and that we eventually forgot. What about accountants?

\section{On hope and courage}

Most of the people I shared my encounter with did relate to the latter. "I completely understand what you felt in this forest, but for most people, what you wrote about would never speak to them. You will appear like being in the sky somewhere." My friend worried that I would eventually want to publish the essay. "How come that we all have a similar experience, a spiritual life that has been portrayed by societies for millennia, and we are still scared to speak about it? Don't you think it is time for an academic coming out?' I asked him. Poetry and music have accompanied human life since its first moments, yet we continue to be afraid of our emotions and passions. While animals mourn their dead together, human beings are taught to cry alone.

Mythical accounts of Gaia and her Gods have shaped empires for thousands of years, Netflix, video games, their monsters and their tears fabricate millions of daily lives, but writing about trees and their teachings during a pandemic keeps appearing like a dangerous move. It is probably time for us to abandon our fears and cut the umbilical cord that keeps connecting us to the Enlightenment, its empiricism, its rationality and its systematic denial of other systems of knowledge and expression, Indigenous and artistic included (Goldberg, 1993). Academics, in particular, are expected to engage in a form of relational accounting that respects the codes and beliefs of modern science, as if a story could instil less than a formula. Is our mission really the one portrayed by Supertramp: Sending people away to teach them how to be clinical, intellectual, cynical?

The pandemic showed us that another reality is possible. We are mortal. We are not alone. And we do feel. Now, where do we go from here? What does it mean for our accounting fabric? Here a proposition: What about imagining different forms of accountability and weaving them into our reporting systems? We could, for instance, include Gaia and her spirits in the accounting system of a conservation impact bond. What would that mean? Instead of evaluating the impact of environmental efforts only through the financial appraisal of the services ecosystems offer to humans, we would add an Indigenous form of accounting that would acknowledge the spiritual life of the trees, the 
rivers and their stones, just because they are alive and worth being embraced [1]. Why so? Because, today, Indigenous peoples represent $5 \%$ of the population, yet are the stewards of $80 \%$ of the biodiversity of the planet [2]. It is their celebration of their spiritual relationships with Mother Earth that has enabled them to protect her fauna and flora, not their economic valuation of the latter (Beckford et al., 2010). Maybe we could acknowledge it and do the same.

Impossible? Come on [...] The pandemic showed us that everything is possible: Have you already forgotten? Let us stop being afraid of our humanity. We are our brains, our hearts, our bodies and our souls. For centuries, accounting systems encompassed each of this dimension, and societies kept flourishing (Descola, 2013). Time has come for us to bring back the alternative worldviews we attempted to silence for so many years, an endeavor from which we have been the first victims. If I had one wish for the aftermath of this crisis, it would be that we all continue to get excited when seeing life arises and sad when death wins. Those are those emotions that make us who we are and where we are. If relational accounting can contribute to this enterprise, then let us celebrate it too.

\section{On the coming grief}

The pandemic that unfolded is nothing in comparison to the collective grief of the planet we will have to go through in the coming years: the birds, the glaciers, the corals, the beaches and the memories of a forever gone land. Gaia will never be the same (Lovelock, 2000). As the virus, she is very much alive and, as many of us, she is dying (Steffen et al., 2015). We will not be able to save every one: Many living species and their spirits will disappear. Like in this forest during the pandemic, let us use accounting to speak our truths, mourn those we are killing and reconcile ourselves with each other, our past, our ecosystems and our future [3].

Let us stop being afraid. Let us embrace the trees, the stories, the emotions, the colors, the music, the drawings, the stones and the writing to reconnect ourselves to the world we belong. There is a fading planet out there that will need to be remembered and a new one that will need to be cherished. So, let us bring back the poets, the artists, the singers, the healers and the story tellers in our accounting realm. Each and any of our accounting selves will be needed, shall we want to build a collective all again? Alone, but together. Here a second proposition: What about building a joint art and scientific piece as a way to account to each other for the disappearance of Gaia in a way that we could collective mourn her and [...] envision a new normal [4]? As it is the moment to restore the Indigenous views in our accounting of the world, it is also probably the time to bring back the arts and humanities into our discipline and cherish their ways of accessing and accounting for the world. Impossible? Come on [. . .] A pangolin in the middle of nowhere paralyzed the entire planet and you are still having doubts?

During this time of pandemic, the forest taught me some secrets about life, her peoples and their accounting that no one else could have shared. I am grateful that trees chose to speak to me and that you did listen to them too. Yet I still had not answered this question: "Were the trees slower to bloom than usual?" Actually, they were, but only to compensate for the quick winter: "A polar vortex has been sitting over the North Pole for much of winter and has helped bottle up the Artic air and keep conditions relatively mild across Canada. [...] That polar vortex is now breaking down over the pole and a large chunk of it will be setting up shop across eastern half of Canada." [5] "It makes sense." I thought. "Everything is a question of equilibrium. We are a system after all. What has to come, has to go."
What trees taught me about Covid-19 


\section{AAAJ}

35,2

\section{4}

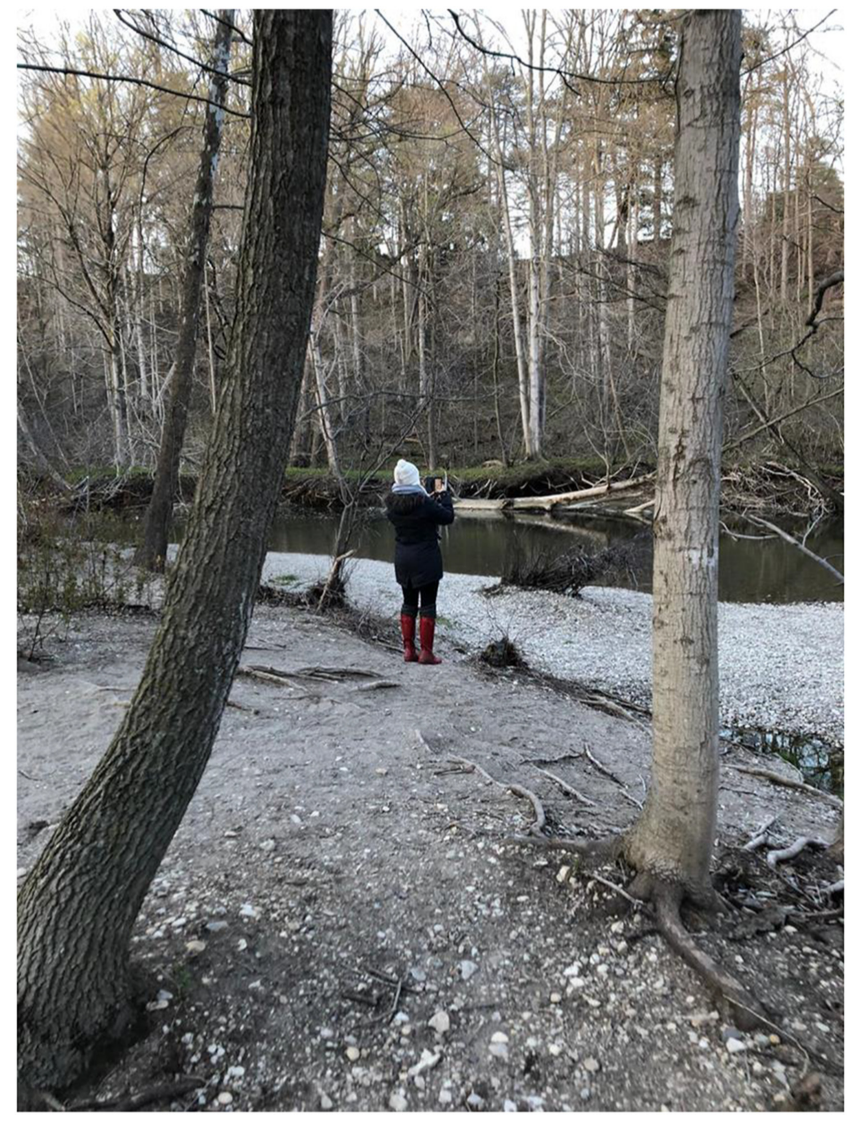

Photographing the beaver: Naming our relations to the world to make them exist (courtesy: my friend, 4 May 2020, Sherwood Forest, London, Ontario, Canada)

The relationship between the river and myself is also featured here: https://www.youtube. $\mathrm{com} /$ watch? $\mathrm{v}=\mathrm{Z} 4000 \mathrm{PoQRwY} \&$ feature=youtu.be.

Diane-Laure Arjalies Ivey Business School, Western University, London, Canada

\section{Notes}

1. Ongoing project with First Nations Communities in the region of Southwestern Ontario, Canada. For more information, ask the author.

2. https://www.unenvironment.org/zh-hans/node/477, accessed 5 May 2020.

3. Such project is developed in further details in Latour (2013). See also Bebbington et al. (2019).

4. Ongoing project in the Forest City, London, Ontario, Canada. For more information, ask the author.

5. Global News, Southern Ontario in for record-setting cold in time for Mother's Day weekend, posted by Anthony Farnell, 4 May 2020, https://globalnews.ca/news/6902104/southern-ontario-record-coldmothers-day-may/ 
6. "There is an emerging and compelling desire to put the events of the past behind us so that we can work towards a stronger and healthier future. The truth telling and reconciliation process as part of an overall holistic and comprehensive response to the Indian Residential School legacy is a sincere indication and acknowledgment of the injustices and harms experienced by Aboriginal people and the need for continued healing. This is a profound commitment to establishing new relationships embedded in mutual recognition and respect that will forge a brighter future. The truth of our common experiences will help set our spirits free and pave the way to reconciliation." Mandate of the Truth and Reconciliation Commission of Canada, 2015, accessible at http://www.trc.ca/about-us/ourmandate.html

\section{What trees taught me about Covid-19}

\section{References}

Bebbington, J., Österblom, H., Crona, B., Jouffray, J.-B., Larrinaga, C., Russell, S. and Scholtens, B. (2019), "Accounting and accountability in the Anthropocene", Accounting, Auditing and Accountability Journal.

Beckford, C.L., Jacobs, C., Williams, N. and Nahdee, R. (2010), "Aboriginal environmental wisdom, stewardship, and sustainability: lessons from the Walpole Island First Nations, Ontario, Canada", The Journal of Environmental Education, Vol. 41, pp. 239-248.

Descola, P. (2013), Beyond Nature and Culture, University of Chicago Press.

Goldberg, D.T. (1993), Racist Culture: Philosophy and the Politics of Meaning, Wiley.

Latour, B. (2013), An Inquiry into Modes of Existence: An Anthropology of the Moderns, Harvard Business Press, Cambridge, MA.

Lovelock, J. (2000), Gaia: A New Look at Life on Earth, Oxford Paperbacks.

Steffen, W., Richardson, K., Rockström, J., Cornell, S.E., Fetzer, I., Bennett, E.M., ... Folke, C. (2015), "Planetary boundaries: guiding human development on a changing planet", Science, Vol. 347 No 6223, p. 1259855.

Wherry, F.F. (2016), "Relational accounting: a cultural approach", American Journal of Cultural Sociology, Vol. 4 No 2, pp. 131-156. 